\title{
The Importance of Cryopreserved Parathyroid Tissue Autotransplantation in the Hypoparathyroidism Treatment after Secondary Hyperparathyroidism Surgery
}

\author{
Sekonder Hiperparatiroidi Cerrahisi Sonrasında Gelişen Hipoparatiroidinin \\ Tedavisinde Dondurularak Saklanan Paratiroid Dokularının Ototransplantasyonunun \\ Önemi
}

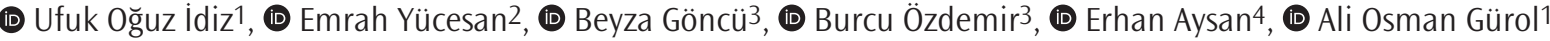 \\ 1 istanbul University, Aziz Sancar Experimental Medicine Research Institute, Department of Immunology, i̇stanbul, Turkey \\ 2Bezmiâlem Vakıf University, Institute of Life Sciences and Biotechnology, İstanbul, Turkey \\ ${ }^{3}$ Bezmiâlem Vakıf University, Research Center, i̇stanbul, Turkey \\ ${ }^{4}$ Yeditepe University Faculty of Medicine, Department of General Surgery, İstanbul, Turkey
}

\begin{abstract}
Introduction: Severe hypocalcemia is a rare but serious complication of secondary hyperparathyroidism (SH) surgery. Continuous intravenous calcium replacement is required and patients are not discharged. Cryopreserved parathyroid autotransplantation (CPA) is the most effective and lasting treatment option for severe hypocalcemia. However, a cryopreservation laboratory is necessary for this procedure.

Methods: Subtotal parathyroidectomy performed 150 SH cases (age range: 26-69 years, mean age: 39.5 years, men/women: $2 / 1$ ) were retrospectively evaluated. Severe hypocalcemia (serum calcium level of $<6.5 \mathrm{mg} / \mathrm{dL}$ ) was developed in 7 (4.6\%) cases. CPA was performed and cases were observed in a minimum of 18 months.

Results: After transplantation in five cases, intravenous and oral calcium replacement was ceased and cases were discharged. Transplantation failed in two cases, thus second time CPA. After the second CPA, intravenous calcium is ceased and cases were discharged. Any side effects or complications were not seen during the observation period.

Conclusion: CPA is the most effective and lasting treatment option for severe hypocalcemia. CPA is not difficult to perform but a cryopreservation laboratory and experienced laboratory team are necessary for this procedure. The presence of this laboratory in SH surgery performed centers reduces the risk of mortality and morbidity.
\end{abstract}

Keywords: Cryopreservation, parathyroid, severe hypoparathyroidism, autotransplantation

\section{öZ}

Amaç: Şiddetli hipokalsemi, sekonder hiperparatiroidizm (SH) cerrahisinin nadir fakat ciddi bir komplikasyonudur. Sürekli intravenöz kalsiyum replasmanı gerekebilir ve hastalar hastaneden taburcu edilemez hale gelebilir. Dondurularak saklanmıs paratiroid dokusunun ototransplantasyonu, șiddetli hipokalsemi için en etkili ve kalııı tedavi seçeneğidir. Ancak bu işlem için kriyoprezervasyon laboratuvarı gerekebilir.

Yöntemler: Subtotal paratiroidektomi yapılan 150 SH olgusu (yaş aralı̆̆ı: 26-69, ortalama yaș: 39,5, erkek/kadın: 2/1) retrospektif olarak değerlendirildi. Yedi $(\% 4,6)$ olguda şiddetli hipokalsemi (serum kalsiyum düzeyi $<6,5 \mathrm{mg} /$ dL) geliști. Bu olgulara dondurularak saklanmış paratiroid dokusunun ototransplantasyonu yapılmış ve olgular en az 18 ay gözlemlenmiștir.

Bulgular: Beş hasta transplantasyon sonrası intravenöz ve oral kalsiyum replasmanı kesilerek taburcu edildi. İki olguda ise transplantasyon başarısız oldu ve onlara ikinci kez paratiroid ototransplantasyonu uygulandı. İkinci transplantasyon sonrası intravenöz kalsiyum kesilerek hastalar taburcu edildi. Hiçbir olguda 18 aylık gözlem süresinde herhangi bir yan etki veya komplikasyon görülmedi.

Sonuç: Dondurularak saklanmış paratiroid dokusunun ototransplantasyonu, șiddetli hipokalsemi için en etkili ve kalıcı tedavi seçeneğidir. Bu transplantasyonu yapmak zor değildir ancak bu işlem için kriyoprezervasyon laboratuvarı ve deneyimli laboratuvar ekibi gereklidir. SH cerrahisi yapılan merkezlerde bu laboratuvarın bulunması mortalite ve morbidite riskini azaltmaktadır.

Anahtar Kelimeler: Krioprezervasyon, paratiroid, șiddetli hipoparatiroidizm, ototransplantasyon
Address for Correspondence/Yazıșma Adresi: Ufuk Oğuz İdiz MD, İstanbul University, Aziz Sancar Experimental Medicine Research Institute, Department of Immunology, İstanbul, Turkey

Phone: +90 2124596000 E-mail: oguzidiz@yahoo.com ORCID ID: orcid.org/0000-0002-8462-7809

Cite this article as/Atıf: İdiz UO, Yücesan E, Göncü B, Özdemir B, Aysan E, Gürol AO. The Importance of Cryopreserved Parathyroid Tissue Autotransplantation in the Hypoparathyroidism Treatment after Secondary Hyperparathyroidism Surgery. İstanbul Med J 2021; 22(4): 275-9.

(c) Copyright 2021 by the University of Health Sciences Turkey, Istanbul Training and Research Hospital/istanbul Medical Journal published by Galenos Publishing House.

(C) Telif Hakkı 2021 Sağıı Bilimleri Üniversitesi İstanbul Ĕğitim ve Araștırma Hastanesi/istanbul Tıp Dergisi, Galenos Yayınevi tarafından basılmıștır.
Received/Gelis Tarihi: 28.06.2021 Accepted/Kabul Tarihi: 21.08.2021 


\section{Introduction}

Secondary hyperparathyroidism (SH) is usually associated with chronic renal failure (1-3). Parathyroidectomy is required in $15 \%$ of patients undergoing dialysis within the first 10 years and 38\% during the first 20 years (4-6). Total parathyroidectomy or subtotal parathyroidectomy with intraoperative parathyroid autotransplantation is the most common surgical procedure (1-3). One of the major complications observed after any thyroidectomy and SH surgery is hypoparathyroidism. Transient hypoparathyroidism after SH surgery occurs in up to $90 \%$ of patients, whereas permanent hypoparathyroidism in up to $20 \%$ (3).

Parathyroid autotransplantation was first described by Halsted (7) in dogs. This procedure was later extensively used in thyroid surgeries (in cases of accidentally removed parathyroid tissues) and SH surgeries (810). The parathyroid autotransplantation was traditionally performed as an intraoperative procedure with fresh tissues. According to subsequent scientific and technological developments, excised fresh tissues transferred from operating rooms to the laboratories were frozen to preserve their viability. Thus, many tissues such as the ovum, sperm, pancreas islet cells, meniscus, trachea, teeth, and parathyroid are safely cryopreserved and de-froze for auto or allotransplantation when necessary (11).

Cryopreserved parathyroid autotransplantation (CPA) was first performed by Wells and Christiansen (12) in 1974. Later, this process was used with different techniques in many scientific studies $(13,14)$.

SH operations are performed in many centers; however, the CPA was not a widespread procedure due to the high cost in setting up the cryopreservation laboratory and qualified personnel requirements.

Cryopreservation laboratory is necessary for SH surgery performing centers because severe hypocalcemia causes a cardiac arrhythmia, fibrillation, and cardiac arrest. Serious risks severe hypocalcemia cases need continuous intravenous calcium replacement and intensive hospital care (15).

In this study, we presented our results of CPA in cases of severe hypocalcemia after SH surgery.

\section{Methods}

A retrospective clinical research was designed and applied to the local human ethics committee. After research protocol approval by the University of Health Sciences Turkey, İstanbul Training and Research Hospital Ethics Committee (approval number: 2879, date: 18.06.2021), informed consent was obtained from all participants. A total of 150 patients (age range: 26-69 years, mean age: 39.5 years, men/women: 2/1) underwent SP between June 2013 and December 2017 in the department of endocrine surgery. All patients underwent standard subtotal parathyroidectomy, which removed all three parathyroid tissues and half of the fourth parathyroid tissue. Excised parathyroid tissues were cut into two pieces. One piece was sent to the pathology laboratory for histopathological examination and the other piece was prepared to be sent to the cryopreservation laboratory.

The parathyroid capsule and other surrounding tissues were carefully dissected from the parathyroid tissues to be sent to the cryopreservation laboratory. After washing the tissues several times with physiological saline, they were transferred to the laboratory by placing them in Falcon tubes of $15 \mathrm{~mL}$ volume containing phosphate buffer solution (PBS). Cell isolation was performed according to the protocol described below.

\section{Parathyroid Cell Isolation and Cryopreservation}

Tissues were received in the laboratory by an experienced biologist. In a negative pressure sterile cabinet, tissues are taken into a sterile vial shredded mechanically with a scalpel and filtered with a cell strainer (70 $\mu \mathrm{m}$, BD Biosciences ${ }^{\circ}$, USA). Filtered cells are collected in $5 \mathrm{~mL}$ PBS and centrifuged at $270 \mathrm{~g}$ for $5 \mathrm{~min}$ at room temperature. The supernatant was removed, and cells were re-suspended in $1 \mathrm{~mL}$ PBS. Cell viability was assessed with a Muse ${ }^{\mathrm{TM}}$ Cell Analyzer (Merck Millipore ${ }^{\star}$, Germany). Cells were cryogenically stored in PBS containing 10\% of dimethyl sulfoxide (AppliChem, Germany) using an isopropanol-based freezing container and then stored in a liquid nitrogen tank.

The cells are prepared for transplantation according to the protocol described below when CPA is decided in patients whose cells were previously cryopreserved.

\section{Preparation of Cells for Transplantation}

The cells in the liquid nitrogen tank were removed and placed in an incubator (ESCO, Singapore) at $37^{\circ} \mathrm{C}$ with a $5 \%$ carbon dioxide-humidified atmosphere. After cultivation for approximately 72 hours, cells were collected and centrifuged at $270 \mathrm{~g}$ for $7 \mathrm{~min}$ at room temperature. The supernatant was removed and cells were re-suspended in $2 \mathrm{~mL}$ PBS.

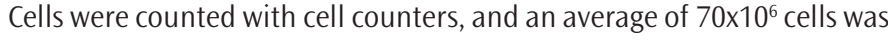
injected into the deltoid muscle of the non-dominant arm of patients.

After the transplantation, patients were observed in the endocrine surgery clinic. Intravenous calcium supplementation was gradually reduced. The patient was discharged when he became asymptomatic without taking any intravenous calcium and his serum calcium and parathormone (PTH) levels were elevated. Discharged patients were followed up weekly during the first month; then at 2, 4, and 6 months; and finally, at 6-month intervals at the outpatient clinic.

\section{Statistical Analysis}

Data of patients were entered into the Statistical Package for the Social Sciences 21 (IBM, Armonk, NY, USA) program, and the desired parameters were given by specifying the mean \pm standard deviation, as well as the minimum and maximum values.

\section{Results}

Severe hypocalcemia was accepted as a serum calcium level of $6.5 \mathrm{mg} / \mathrm{dL}$ or less in the postoperative period. Symptomatic severe hypocalcemia at postoperative day one was observed in 23 (15.3\%) of 150 patients. Mean serum calcium level was $5.61 \pm 3.05 \mathrm{mg} / \mathrm{dL}$ (range: 4.0-6.5 mg/dL) and the mean serum PTH level was $62.63 \pm 125.68 \mathrm{pg} / \mathrm{mL}$ (range: 0-285 pg/ $\mathrm{mL}$ ). These patients were followed for 1 week with intravenous and oral calcium plus vitamin D supplementation, which is a routine practice in our clinic. Up to the seventh postoperative day, 16 (10.7\%) patients 
did not require intravenous calcium supplements; their symptoms almost disappeared, and were discharged. Intravenous and oral calcium plus vitamin D supplementations were administered; however, the serum calcium levels remained below $6.5 \mathrm{mg} / \mathrm{dL}$ in 7 (4.6\%) patients and continued to be symptomatic. All patients were evaluated in the endocrine council and CPA was decided.

The mean age of the seven patients who underwent CPA was 44.5 \pm 8.5 (range: 22-56) years, and the female to male ratio was 1.33 . The serum PTH and calcium changes of patients are shown in Table 1, 2.

After CPA, except for two cases, serum PTH and calcium levels increased, symptoms decreased, intravenous calcium supplementation ceased, and patients were discharged. However, serum PTH and calcium levels were decreased at very low levels in cases 1 and 2 . In case 1 serum PTH levels were $3 \mathrm{pg} / \mathrm{mL}$ and $1.3 \mathrm{pg} / \mathrm{mL}$, serum calcium level at $6 \mathrm{mg} /$ $\mathrm{dL}$ and $5.5 \mathrm{mg} / \mathrm{dL}$ in postoperative week 1 and month 1, respectively. In case 2, serum PTH levels were $2.5 \mathrm{pg} / \mathrm{mL}$ and $2.5 \mathrm{pg} / \mathrm{mL}$ and serum calcium level were $5.5 \mathrm{mg} / \mathrm{dL}$ and $5.6 \mathrm{mg} / \mathrm{dL}$ in postoperative week 1 and month 1, respectively (Table 1, 2). Occasional intravenous calcium infusion is required and symptoms persisted. In these cases, the second CPA was performed 3 months after the first transplantation. Serum PTH and calcium levels increased, symptoms disappeared, and intravenous calcium supplementations were ceased.

Serum PTH and calcium values were observed in all cases, which underwent CPA, at least 18 months (range: 18-25 months). None of the patients required intravenous or oral calcium supplementation. Only cases 1 and 2 were continued to take oral calcium effervescent tablets daily. None of the patients had local or systemic side effects or complications.

Table 1. PTH $(\mathrm{pg} / \mathrm{mL})$ value changes of the autotransplantation cases

\begin{tabular}{|c|c|c|c|c|c|c|c|c|}
\hline & Preop & Postop day 7 & Post Tx week 1 & Post Tx month 1 & Post Tx month 3 & Post Tx month 6 & Post Tx month 12 & Post Tx month 18 \\
\hline Case 1 & 2308 & 1.9 & 3 & 1.3 & $12.9 *$ & 14 & 14 & 14 \\
\hline Case 2 & $>3500$ & 0 & 2.5 & 2.5 & $7.5^{*}$ & 11 & 12 & 12 \\
\hline Case 4 & 3235 & 67 & 70 & 75 & 74 & 87 & 85 & 85 \\
\hline Case 5 & 2764 & 28 & 32 & 34 & 38 & 38 & 38 & 38 \\
\hline
\end{tabular}

*: Second Tx performed, PTH: Parathormone, Preop: Preoperative, Postop: Postoperative

\section{Discussion}

Severe hypoparathyroidism is a rare complication of thyroid and SH surgery $(3,16)$. When hypoparathyroidism is not severe, patients are discharged from the hospital with oral calcium and vitamin D preparations. In severe hypocalcemia, patients are impossible to be discharged due to continuous intravenous calcium infusion.

Falls due to muscle spasms or weakness and fall-related bone fractures are the main morbidity mechanisms, and cardiac arrest due to hypocalcemic myocardial fibrillation is the main mechanism of mortality of these cases (15). Four options for severe hypoparathyroidism management are as follows: a continuous intravenous calcium infusion, subcutaneous recombinant PTH injection, parathyroid allotransplantation, and CPA (13,17-19).

Continuous intravenous calcium infusion is an easy and inexpensive option; however, this approach requires appropriate hospital conditions and follow-up by an experienced clinician. Rapid and high-dose infusions increase the risk of myocardial fibrillation. The clinical effect of intravenous calcium infusion occurs rapidly (within minutes), but with short-term effectiveness (within hours) $(17,20)$.

A recombinant PTH injection is a fast-acting option like an intravenous calcium infusion and does not require follow-up in hospital settings (21). However, it is very expensive and, in many countries, is not covered by the social insurance system.

Parathyroid allotransplantation is a process that requires a specific laboratory, experienced multidisciplinary staff from the clinical (internal medicine, endocrinology, endocrine surgery, etc), and biological sciences $(22,23)$. In the literature, some case reports and very limited clinical series are available about parathyroid allotransplantation $(19,23)$.

Table 2. Calcium $(\mathrm{mg} / \mathrm{dL})$ value changes of the autotransplantation cases

\begin{tabular}{|c|c|c|c|c|c|c|c|c|}
\hline & Preop & Postop day 1 & Post Tx week 1 & Post Tx month 1 & Post Tx month 3 & Post Tx month 6 & Post Tx month 12 & Post Tx month 18 \\
\hline Case 1 & 9.7 & 6.1 & 6 & 5.5 & $6.4^{*}$ & 6.9 & 6.8 & 6.8 \\
\hline Case 2 & 11.9 & 5.7 & 5.5 & 5.6 & $6.1^{*}$ & 6.9 & 6.8 & 7 \\
\hline Case 4 & 9.7 & 6.1 & 7.7 & 8 & 8.3 & 8.1 & 8.7 & 8.5 \\
\hline Case 5 & 10 & 5.3 & 6.8 & 6.9 & 7 & 8.1 & 7.5 & 8.1 \\
\hline
\end{tabular}


Our center is the unique parathyroid allotransplantation center in Turkey approved by the Turkey Ministry of Health. In our center, tissues obtained from SH surgery as donors in parathyroid allotransplantations are used. Therefore, many patients who underwent $\mathrm{SH}$ are referring to our center, thus many SH surgeries are performed (24).

CPA is one of the most effective and also natural treatment options if excised parathyroid tissues are cryopreserved during SH surgery (25). Since the patient's tissues are used, an immunological reaction is not a risk, thus no immunosuppression is required $(14,26)$. The most important limitation of this treatment option is the need for a specific cryopreservation laboratory and experienced biologist staff.

Different results were reported in the literature regarding the success of autotransplantation after cryopreservation of parathyroid tissue $(14,26,27)$. Shepet et al. (27) reported that four patients who developed severe hypoparathyroidism after SH surgery underwent a CPA, of which only 1 was successful. Agarwal et al. (14) reported a success rate of $100 \%$ as a result of CPA in nine patients.

Schneider et al. (26) reported a 100\% success rate in a series of 606 patients who underwent SH surgery and 13 patients who received CPA due to severe hypoparathyroidism. Another study reported that CPA was performed in a total of 25 patients with severe hypoparathyroidism following surgical interventions (secondary, persistent, and recurrent hyperparathyroidism) with different indications. Complete success was reported in 16 patients and partial success in 9 (28).

The significant differences in CPA success rates in the literature are mainly due to the laboratory process, as well as the donor cell quality and quantity $(14,26,27)$. The laboratory process has two main stages: freezing and de-freezing $(14,29)$. Freezing is start when the tissues are removed from the patient. This stage consists of multiple steps, including fast transportation from the operating room to the laboratory at a body temperature, cell isolation into the sterile cabin, centrifugation, cell storage in proper medium, $-80{ }^{\circ} \mathrm{C}$ freezing in one night, and transfer to the liquid nitrogen tank. The de-freezing stage consists of taking cells out of the liquid nitrogen tank and heating them to $36{ }^{\circ} \mathrm{C}$, culture medium incubation, cell counting, transportation to the patient room in a sterile tube at body temperature, and transplant to the patient via intramuscular injection $(14,30)$. Incorrect and inadequate implementation of any of these steps will affect all subsequent steps and will therefore determine the CPA's success.

In 150 cases, the incidence of hypoparathyroidism was 4.6\% (7 cases) in our series, who underwent SH surgery, which is consistent with other series in the literature $(3,6)$. Our CPAs were performed with three experienced laboratory staff (two postdocs and one medical biologist) in our parathyroid transplant laboratory with specific devices for parathyroid tissue. Our relatively high success rate is related to our experienced surgical team, laboratory team, and laboratory infrastructure.

In two cases, second transplantation was performed because symptoms persisted and serum calcium and PTH levels were not elevated. After the second transplantation, symptoms disappeared, and serum calcium and
PTH levels were elevated, thus intravenous calcium infusion was ceased and cases were discharged from the hospital.

\section{Conclusion}

Therefore, severe hypocalcemia is a rare but life-threatening complication of SH surgery. In addition to oral supplementation, these cases require continuous intravenous calcium infusion in hospital conditions. CPA is the most effective and lasting treatment option for these cases. CPA is not difficult to perform but it necessitates a cryopreservation laboratory and experienced laboratory team. The presence of this laboratory in SH surgery performing centers reduces the risk of mortality and morbidity.

Ethics Committee Approval: This study approval by the University of Health Sciences Turkey, İstanbul Training and Research Hospital Ethics Committee (approval number: 2879, date: 18.06.2021).

Informed Consent: Informed consent was obtained from all participants.

Peer-review: Externally peer-reviewed.

Authorship Contributions: Concept - U.O.I.; Design - U.O.I., E.A.; Supervision - E.A.; Resources - U.O.I., E.Y., B.G., B.Ö.; Materials - U.O.I., E.Y., B.G., B.Ö.; Data Collection or Processing - U.O.I., E.Y., B.G., B.Ö., E.A.; Analysis or Interpretation - U.O.I., E.Y., B.G., B.Ö., E.A.; Literature Search - U.O.I., E.Y., B.G., B.Ö., A.O.G.; Writing - U.O.I., E.Y., B.G., B.Ö.; Critical Review - E.A.

Conflict of Interest: No conflict of interest was declared by the authors.

Financial Disclosure: The authors declared that this study received no financial support.

\section{References}

1. Tominaga Y, Kohara S, Namii Y, Nagasaka T, Haba T, Uchida K, et al. Clonal analysis of nodular parathyroid hyperplasia in renal hyperparathyroidism. World J Surg 1996; 20: 744-52.

2. Malberti F, Marcelli D, Conte F, Limido A, Spotti D, Locatelli F. Parathyroidectomy in patients on renal replacement therapy: an epidemiologic study. J Am Soc Nephrol 2001; 12: 1242-8.

3. Neagoe RM, Mureșan M, Voidăzan S, Paşcanu I, Radu CP, Sala DT. Subtotal parathyroidectomy versus total parathyroidectomy with autotransplant in secondary hyperparathyroidism - a single-centre prospective cohort of 43 patients. Endokrynol Pol 2016; 67: 202-9.

4. Shih ML, Duh QY, Hsieh CB, Lin SH, Wu HS, Chu PL, et al. Total parathyroidectomy without autotransplantation for secondary hyperparathyroidism. World J Surg 2009; 33: 248-54

5. Fassbinder W, Brunner FP, Brynger H, Ehrich JH, Geerlings W, Raine AE, et al. Combined report on regular dialysis and transplantation in Europe, XX, 1989. Nephrol Dial Transplant 1991; 6(Suppl1): 5-35.

6. Gasparri G, Camandona M, Abbona GC, Papotti M, Jeantet A, Radice E, et al. Secondary and tertiary hyperparathyroidism: causes of recurrent disease after 446 parathyroidectomies. Ann Surg 2001; 233: 65-9.

7. Halsted WS. Auto- and isotransplantation, in dogs, of the parathyroid glandules. J Exp Med 1909; 11: 175-99.

8. Wells SA Jr, Gunnells JC, Shelburne JD, Schneider AB, Sherwood LM Transplantation of the parathyroid glands in man: clinical indications and results. Surgery 1975; 78: 34-44. 
9. Lahey FH. The transplantation of parathyroids in partial thyroidectomy. Surg Gynecol Obstet 1926; 62: 508-9.

10. Fisher B, Fisher ER, Feduska N, Sakai A. Thyroid and parathyroid implantation: an experimental re-evaluation. Surgery 1967; 62: 1025-38.

11. Meneghel J, Kilbride P, Morris GJ. Cryopreservation as a Key Element in the Successful Delivery of Cell-Based Therapies. A Review. Front Med (Lausanne) 2020; 7: 592242

12. Wells SA Jr, Christiansen C. The transplanted parathyroid gland: evaluation of cryopreservation and other environmental factors which affect its function. Surgery 1974; 75: 49-55.

13. Borot S, Lapierre V, Carnaille B, Goudet P, Penfornis A. Results of cryopreserved parathyroid autografts: a retrospective multicenter study. Surgery 2010; 147 : 529-35.

14. Agarwal A, Waghray A, Gupta S, Sharma R, Milas M. Cryopreservation of parathyroid tissue: an illustrated technique using the cleveland clinic protocol. J Am Coll Surg 2013; 216: e1-9.

15. Fong J, Khan A. Hypocalcemia: Updates in diagnosis and management for primary care. Can Fam Physician 2012; 58: 158-62.

16. Isik A, Firat D, Yilmaz I, Peker K, Idiz O, Yilmaz B, et al. A survey of current approaches to thyroid nodules and thyroid operations. Int J Surg 2018; 54 : $100-4$

17. Cooper MS, Gittoes NJ. Diagnosis and management of hypocalcaemia. BMJ 2008; 336: 1298-302.

18. Bilezikian JP, Brandi ML, Cusano NE, Mannstadt M, Rejnmark L, Rizzoli R, et al. Management of hypoparathyroidism: Present and future. J Clin Endocrinol Metab 2016; 101: 2313-24.

19. Aysan E, Altug B, Ercan C, Kesgin Toka C, Idiz UO, Muslumanoglu M. Parathyroid allotransplant with a new technique: a prospective clinical trial. Exp Clin Transplant 2016; 14: 431-5.
20. Henderson AK, Mahony 0. Hypoparathyroidism: Treatment*. Compendium 2005; 27: 280-7.

21. Cusano NE, Rubin MR, Bilezikian JP. PTH(1-84) replacement therapy for the treatment of hypoparathyroidism. Expert Rev Endocrinol Metab 2015; 10 : 5-13.

22. Aysan E, Kilic U, Gok O, Altug B, Ercan C, Kesgin Toka C et al. Parathyroid allotransplant for persistent hypocalcaemia: a new technique Involving shortterm culture. Exp Clin Transplant 2016; 14: 238-41.

23. Barczyński M, Gołkowski F, Nawrot I. Parathyroid transplantation in thyroid surgery. Gland Surg 2017; 6: 530-6.

24. Aysan E, Çilem E, Akbaş F, Toka CK, Kandaş N, Başoğlu H et al. Parathyroid allotransplantation without continuous Immunosupression: prospective clinical series on 44 cases. Turkiye Klinikleri J Gen Surg-Special Topics 2016; 9: 63-9.

25. Nawrot I, Woźniewicz B, Tołłoczko T, Sawicki A, Górski A, Chudziński W et al. Allotransplantation of cultured parathyroid progenitor cells without immunosuppression: clinical results. Transplantation 2007; 83: 734-40.

26. Schneider R, Slater EP, Karakas E, Bartsch DK, Schlosser K. Initial parathyroid surgery in 606 patients with renal hyperparathyroidism. World J Surg 2012; 36: $318-26$.

27. Shepet K, Alhefdhi A, Usedom R, Sippel R, Chen H. Parathyroid cryopreservation after parathyroidectomy: a worthwhile practice? Ann Surg Oncol 2013; 20: 2256-60.

28. Wagner PK, Seesko HG, Rothmund M. Replantation of cryopreserved human parathyroid tissue. World J Surg 1991; 15: 751-5.

29. Guerrero MA, Evans DB, Lee JE, Bao R, Bereket A, Gantela S, et al.Viability of cryopreserved parathyroid tissue: when is continued storage versus disposal indicated? World J Surg 2008; 32: 836-9.

30. Guerrero MA. Cryopreservation of parathyroid glands. Int J Endocrinol 2010 2010: 829540. 